\title{
The varying effects of antibiotics on gut microbiota
}

\author{
Lulu Yang ${ }^{1,2}$, Ousman Bajinka ${ }^{1,2,3}$, Pa Omar Jarju ${ }^{3}$, Yurong Tan ${ }^{1,2,6^{*}} \oplus$, Aji Mary Taal ${ }^{4}$ and Guven Ozdemir ${ }^{5}$
}

\begin{abstract}
Antibiotics are lifesaving therapeutic drugs that have been used by human for decades. They are used both in the fight against bacterial pathogens for both human and for animal feeding. However, of recent, their effects on the gut microbial compositions and diversities have attracted much attention. Existing literature have established the dysbiosis (reduced diversity) in the gut microbiota in association with antibiotic and antibiotic drug doses. In the light of spelling out the varying effects of antibiotic use on gut microbiota, this review aimed at given an account on the degree of gut microbial alteration caused by common antibiotics. While some common antibiotics are found to destroy the common phyla, other debilitating effects were observed. The effects can be attributed to the mode of mechanism, the class of antibiotic, the degree of resistance of the antibiotic used, the dosage used during the treatment, the route of administration, the pharmacokinetic and pharmacodynamics properties and the spectrum of the antibiotic agent. Health status, stress or the type of diet an individual feeds on could be a great proportion as confounding factors. While it is understood that only the bacterial communities are explored in the quest to establishing the role of gut in health, other gut microbial species are somehow contributing to the dysbiosis status of the gut microbiota. Until now, long term natural fluctuations like diseases outbreaks and mutations of the strain might as well rendered alteration to the gut independent of antibiotic treatments.
\end{abstract}

Keywords: Gut microbiota, Dysbiosis, Antibiotics, Gut health, Narrow spectrum, Broad spectrum antibiotics

\section{Introduction}

Antibiotics have been used for decades to prevent the proliferation of bacterial pathogens and thus treatment of bacterial infections. They are used to improve the efficiency of animal feeds (Looft et al. 2012). However, the rate at which bacteria are developing virulence genes enable them to resist these antibiotic. Of recent, the insightful knowledge indicated overuse of antibiotics as impacting gut health. These come with number of health hazardous consequences. Even though antibiotics are saving millions of lives, they are as well reducing residential bacteria and these bacteria are crucial for a healthy gut (Bajinka et al. 2020a, b). Physicians will prescribe broad spectrum antibiotics, often when the pathogen

\footnotetext{
*Correspondence: yurongtan@csu.edu.cn

${ }^{6}$ Department of Microbiology, Xiangya School of Medicine, Central South University, Changsha 410078, Hunan, China

Full list of author information is available at the end of the article
}

is unknown. While narrow-spectrum targets only few types of bacteria, the devastating effects on gut's health is incomparable to that of broad-spectrum (Ghoshal et al. 2016).

With the insight on the role of gut microbiota in health and diseases, factors disrupting the gut microbial compositions and diversities have attracted much scientific interest. Cutting-edge researches have established the dysbiosis in the gut flora and the period of recovery due to the use of antibiotics and other drugs. While antibiotics are much studied, an account on the degree of varying effects on gut microbial alteration caused by non-antibiotics are also studied (Bajinka et al. 2020a, b). The use and or the application of other drugs, orally as medication, use on agriculture, gut recovery and healing are looked into, to give evidence based findings. While some common drugs are found to wash away the common phyla, others debilitating effects were observed up to species
Springer Open
C The Author(s) 2021. Open Access This article is licensed under a Creative Commons Attribution 4.0 International License, which permits use, sharing, adaptation, distribution and reproduction in any medium or format, as long as you give appropriate credit to the original author(s) and the source, provide a link to the Creative Commons licence, and indicate if changes were made. The images or other third party material in this article are included in the article's Creative Commons licence, unless indicated otherwise in a credit line to the material. If material is not included in the article's Creative Commons licence and your intended use is not permitted by statutory regulation or exceeds the permitted use, you will need to obtain permission directly from the copyright holder. To view a copy of this licence, visit http://creativecommons.org/licenses/by/4.0/. 
level. The period of recovery for the gut microbial composition varies with the interventions, the concentration of the drug used, and the length of treatment (Ghoshal et al. 2016). While it is understood that only the bacterial communities are explored in the quest to establishing the role of gut microbiota in disease and health, the alteration of fungal and phage population study will find answers relevant for clinical application.

Previous studies have reached the consensus on degree of known alteration of gut composition. Furthermore, excessive use of antibiotics is associated with some metabolic disorders. Among these, infants and young children are at an increased risk of asthma and weight gain in adults (Vogt and Finlay 2017; Cox and Blaser 2015). Overuse of antibiotic promotes colonization of Clostridium difficile, an opportunistic pathogen causing antibiotic-associated diarrhea (Bajinka et al. 2020a, b; Theriot et al. 2014). It leads to reduction in microbial diversity among intestinal flora (dysbiosis) (Dethlefsen and Relman 2011; Zaura et al. 2015; Rashid et al. 2015). Also it cause reduction in the number of protective species such as Bifidobacterium spp. (Stewardson et al. 2015). A great deal of studies have centered on the effects of antibiotics on the gut microbiota. Consequently, antibiotics are found to be causing numerous alterations to the microbial population, thereby inflicting changes to the physiological functions of the host (Qiu et al. 2021).

Microbial balance is disrupted both in short and long term conditions due to antibiotic treatment. This causes massive reductions in the richness and diversity of the microbial communities (Clemente et al. 2012). A case scenario will be clindamycin, metronidazole and ciprofloxacin. All of these are affecting the structure of microbiota for varying length of time (Bäckhed et al. 2012; Devillard et al. 2009). Moreover, after disrupting our microbiota by antibiotics, humans showed varying length of time to recovery. It has been proven that, this recovery is individual-dependent. There are possible effects to our variation in microbiota prior to antibiotic treatment (Zivkovic et al. 2011; Ouwehand et al. 2002).

Antibiotics are inevitable in today's fight against infectious diseases. However, a high dosage is used in order to be strategic and productive (Bajinka et al. 2020b). One explorative study in humans showed devastating results; $\beta$-lactam intravenous therapy consisting of ampicillin, sulbactam and cefazolin do not only disrupt the microbial ecology but also the production of strong metabolites are affected (Bajinka et al. 2020a). The effect was seen on the production of acetyl phosphate and acetyl-coA (Liu et al. 2020a, b). These are involved in major cellular functions (Zivkovic et al. 2011). Delayed gastrointestinal (GI) tract motility due to the affected secondary bile acid and serotonin metabolism in the colon was seen among the mice whose microbiota was depleted by antibiotics (Ouwehand et al. 2002). The antibiotic-treated mice were found to be very susceptible to antibiotic-associated pathogens, $S$. Typhimurium and C. difficile. Due to the alteration in mucosal carbohydrate availability, pathogens can expand the gut of the mice (Yoshioka et al. 1983).

Gene transfer is stimulated among the bacterial population. A reduction in the immune response by the peripheral organs due to the impaired effects is induced through antibiotic intervention (Looft et al. 2012). One such alteration is in the nutritional landscape of the gut. Instead of destroying only the pathogenic microbes, the number of benign microbes will also be reduced (Qiu et al. 2020). Enterohaemorrhagic E. coli, S. Typhimurium and $C$. difficile all utilize fucose and amino acid liberated by the gut microbiota. For the latter two, an increased level of acid favors healing of their population after antibiotic treatment (Ferreyra et al. 2014; Huang et al. 2015). A schematic illustration shows a hallmark in the use of different forms of antibiotics affecting or inflicting dysbiosis in gut microbiota (Fig. 1).

\section{Antibiotic abuse}

The increase in abuse of antibiotics is undoubtedly causing the increase prevalence of global antibiotics resistance crisis (Liu et al. 2020a, b). While the goal is to receive the correct dosages of the right antibiotics, the cost involved in the medical care resulting from antibiotic abuse during perinatal periods is high (Cardetti et al. 2020). Another form of antimicrobial abuse, which forms the burden of antibiotic use is link to food animal (Adebowale et al. 2020). The genetic capacities of microbes are seen with increasing resistance genes due to overuse of antibiotics. Apparently, bacteria develop multiple mechanisms of resistance against almost all the available antibiotics (Davies and Davies 2010; Munita and Arias 2016). The neurotoxic effect result from abuse of antibiotics works by both local and more prominent systemic mechanisms (Helaly et al. 2019).

The adverse effects of abusing antibiotics include increased microbial resistance and microbiome abnormalities. These abnormalities are called dysbiosis and can lead to autoimmune disorders, gastrointestinal disorders, allergies, infections, arthritis, asthma, cancer and obesity (Cardetti et al. 2020). Abusing antibiotics by taking in excess modifies the gut microbiota and this is studied to be associated with the development of neurological and psychiatric disorders (Helaly et al. 2019). In a bid to cut down the use of antibiotics amid the controlling of abuse of antibiotics and resistance, antimicrobial peptides (AMPs) in combination with some conventional antibiotics are promising (Liu et al. 2020a, b; Pang et al. 2019). 


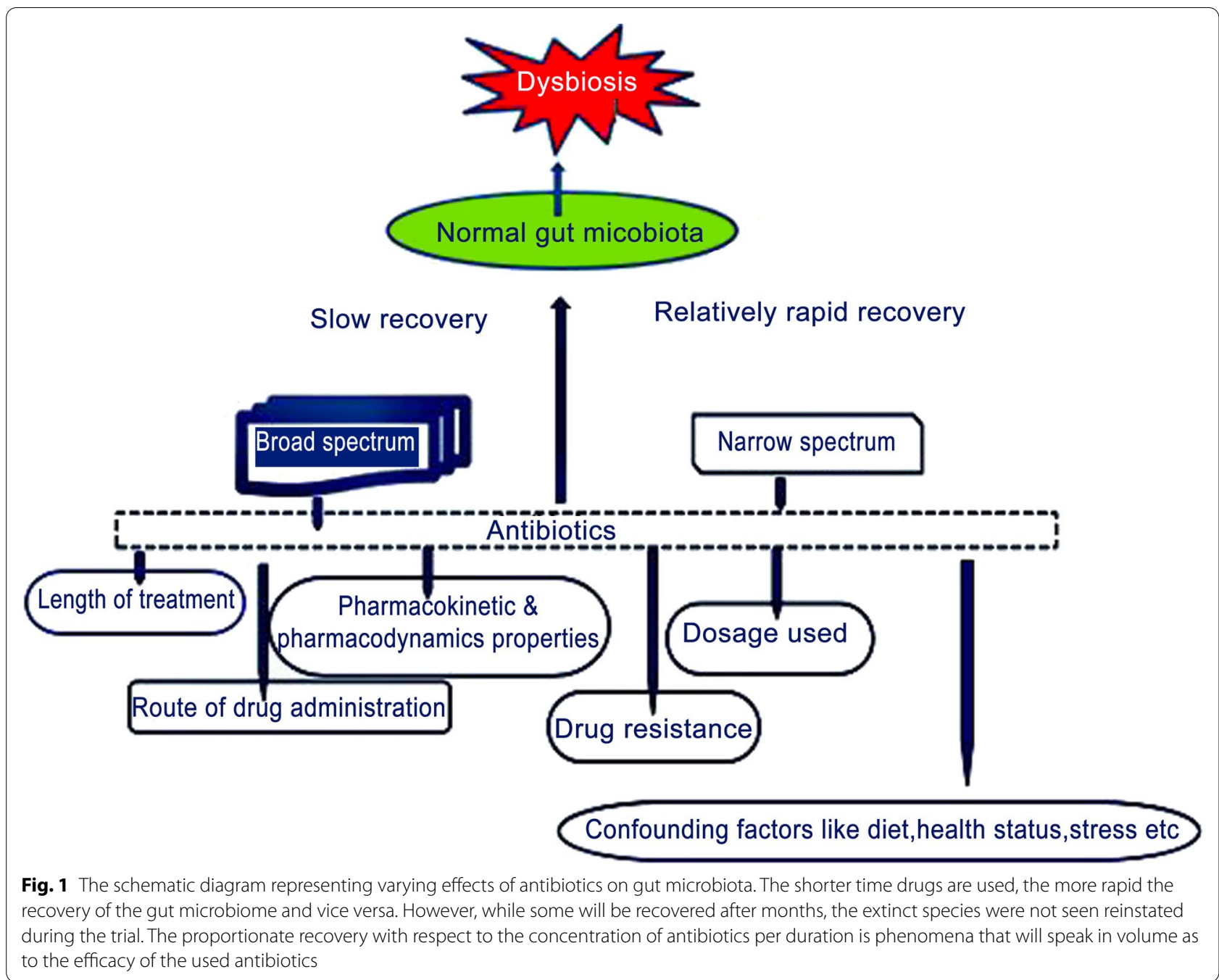

From the recent studies, horizontal gene transfer (HGT) and antibiotic resistance genes happen abundantly in GIT. This has brought number of clinical implications since probiotics, commensals and opportunistic pathogens can survive against antimicrobial medications through transferring resistance genes. Although, gene therapy and personalized medicine could remedy antibiotics resistance, probiotic induced resistant mechanism will require broad interventional study to ascertain the host-specific antibiotic resistant (Daniali et al. 2020).

Since the gut dysbiosis is found to be associated with mucus depletion, inflammation, blood-brain barrier disruption leading to alterations in neuromodulators, patients with drug-resistant epilepsy do suffer from polydrug toxicity (Holmes et al. 2020; Bajinka et al. 2021). A in cohort study of gut microbiota among health individuals in Singapore, high-level tigecycline resistance was detected by the act of tigecycline-inactivating enzyme tet
(X4) (tet 4) on host. Tet(X4)-positive isolated from positive Enterobacteriaceae culture resistance mechanism showed that both E. coli 2EC1-1 and 94EC carry tet(X4), IncI1-type plasmids p2EC1-1 and p94EC-2 respectively (Ding et al. 2020). Amino acid biosynthesis pathways was found to be required for Citrobacter rodentium to colonize the gut in mouse model. However, this pathway is not achievable in antibiotic-treated animals thus exhibiting depletion of amino acids by antibiotics in the gut (Caballero-Flores et al. 2020).

\section{Use of antibiotics on infant gut and diseases}

Gut microbiota is impacted by the early-life antibiotic use. A number of metabolic and immunological diseases are being studied using mouse model. Disrupted microbiome is reflective of the number and types of antibiotic taken. Enough evidence is gathered yet however, the mode of antibiotic delivery is observed 
to exert different magnitudes of effects (Bajinka et al. 2020a). The Metagenomics, phylogenetic and individual record of used antibiotics were the tools for a study conducted in Finland. Among the children between 2 and 7 years, the use of macrolides was observed to be associated with long-lasting shift in the composition of intestinal flora. This affects the human gut metabolism (Korpela et al. 2016). When children under treatment were compared with non-antibiotic treatment group, a clear difference was observed. Abundances of Collinsella, Lactobacillus and Anaerostipes were seen among non-antibiotics exposed children. These population were reduced among children who were treated with antibiotics. Other alterations include; total richness and maturity of the microbiota remained reduced until after 2 years (Imhann et al. 2016). The recovery is not delayed for all the microbial population. Bacteroides and Bifidobacterium are observed to recover back to pre-antibiotic status within 12 months after macrolide course. Ironically, children receiving antibiotics registered bacterial infections more frequently than those who do not receive antibiotics. This can be evidencebased on the interrelation and interdependency of the microbes in the gut (Imhann et al. 2016). Wiping a large amount of number is proportionate to weakening the collective functionalities of commensal bacteria.

Mother-to-infant transmission of antibiotic-resistant strains mechanisms are understudied however, health and immune programming of infants is strongly influenced by the types of bacteria that first colonized the gut (vertical transmission). The predicted mechanisms in vertical antibiotic resistant strain transfer from mother to offspring through transfer of AMR strains through breast milk, preterm births and antibiotic exposure. Transfer in utero and during birth (placenta and vagina), through breast milk and transfer of antibiotics in utero (Tochitani 2021). Neonatal antibiotic exposure of cohort of 12,422 children showed weight and height gain among boys and not girls, higher body mass index (BMI) in both gender and a decreased in the diversity of diversity of fecal Bifidobacteria in the first two years of age. This study was follow up by mice model experiment where FMT from children exposed to antibiotics showed growth impairment (UzanYulzari et al. 2021). Again, the expression of genes associated with deficient thalamocortical axons, impaired outgrowth of thalamic axons and axonogenesis were all reduced in a study group of antibiotic-treated mice thus, antibiotic maternal exposure can influence fetal neurodevelopment (Vuong et al. 2020; Patangia et al. 2021). Offspring allergic lung inflammation is strongly associated with prenatal antibiotic exposure through manipulating the neonatal intestinal environment (Alhasan et al. 2020). Ovalbumin-induced anaphylaxis is specifically common among disturbed neonatal immune system development due to exposure to broadspectrum antibiotic ampicillin. The inability to generate $\mathrm{CD} 4^{+} \mathrm{T}$ cells, colonic regulatory $\mathrm{T}$ cells in particular in colons of antibiotic-impacted microbiota mother lead to Treg deficiency. Consequently, this leads to dysregulated Th1 responses when an infant could develop more severe symptoms amends challenges of bacterial infections (Zhang et al. 2021).

\section{Antibiotic abuse in medical and agricultural purposes}

Several studies have concluded that number of drugs disrupt the microbiota, thereby causing gastrointestinal infections. However, not much interventions have been done in response to this. Just as we experience the side effects of some of the orally taken antibiotics, there is clear evidence that gut microbes are as well affected. In this modern agriculture, despite minimal as claimed, doses of antibiotics given to livestock to increase their growth and weight. This is done with the objectives to maximize profit and minimize cost (Looft et al. 2012). In a nutshell, intensive farmers anticipate quick maturity while ensuring healthy livestock for the market consumption (beef and poultry) (Harris et al. 2018). Ironically, we will have beef and poultry for consumption. However, observational human studies, which are coupled with rodent studies, have proven that antibiotics, even a tiny dose found in food cause obesogenic effects for the consumers. Again, to separate the masses and the use of antibiotics require a thorough and global scientific research. Furthermore, the already conducted interventional studies could not engineer consistent metabolic consequences (de Gunzburg et al. 2018). It is hoped that, more carefully designed studies will iron out these kinks.

In swine gut microbiome, bacterial population are found with antibiotic resistome and was as a result of influx treatment of pigs with antibiotics. Although, this enhance pig production, nonredundant genes are now added to reference gene catalogue (RGC) of the pig gut microbiome and these are resistant genes against aminoglycoside and Tetracycline (Wang et al. 2019). Probiotic bacteria are seen with improved conditions for shrimp aquaculture and hence reduction in the proliferation of antibiotic induced-pathogen (Olmos Soto 2021). For instance, lactic acid bacteria of Enterococcus faecium Z1-2 and Enterococcus faecalis LS1-2 can be used to develop host-specific probiotics (Cui et al. 2017). In a bid to finding alternative to antibiotics, 
supplementation of rhubarb was found to enhance host mucosal innate immune homeostasis. During the early stages of development, rhubarb could modulate intestinal epithelial microbiota. The gut microbiota was found to shifted in favor of Clostridium, Pseudomonas, Blautia, Lactobacillus while a reduction of Staphylococcus was observed (Jiao et al. 2018).

\section{Common antibiotics in use and their effects on gut microbiota}

The effects of one antibiotic is severe than the other when administered on the same concentration. One such variation was seen in the study where ciprofloxacin affects rapidly and profoundly lead to loss of gut microbial diversity. A shift in the community compositions just within few days was seen. Notably, individual variation was considered where relevant in the variability of samples. The temporal variation was seen on daily basis that eventually lead to a complete shift. However, there are a number of stable species that resist antibiotic perturbation. Reverting to normal intestinal microbiota after the intervention is often incomplete as some species will never be regained, yet this is different for each individual (Zaura et al. 2015). This can serve as an evidence that human gut microbiota unlike the ecosystem is dynamic in average stable community while non-resilient for all the species. In sense, just as the effect of mutation, once the genes are mutated, there is no recovery. And hence it is imperative to be highly cautious when debilitation our intestinal microbiota with drugs of unknown consequences (Lange et al. 2016; Langdon et al. 2016).

\section{Clindamycin}

Clindamycin is one of the commonly used broad-spectrum antibiotics. It primarily targets anaerobic bacteria, which are vital in maintaining a healthy gut. Clindamycin is excreted in bile and can reach high concentrations in the colon lumen (Vincent and Manges 2015). This disrupts the gut microbiota, causing a shift in colonization by the bacteria. This conditions give rise to the overgrowth of $C$. difficile (Rashid et al. 2015). This in effect, put the gut at risk of pseudo membranous colitis in contrast to the gut of healthy individuals. Diarrhea and gastritis lead to disturbance of normal bowel function thereby bloating. Intestinal pain is prominent and consequently loss of short chain fatty acids (SCFAs). A long term effect was seen on Bacteriodes in the colon by a repetitive sequence-based PCR (rep-PCR). Persisting resistant bacteria were observed with an increasing trend (Jernberg et al. 2010).

\section{Ciprofloxacin versus clindamycin}

Studies centered on these drugs have observed a delay in the recovery of normal microbiota for 12 months. The loss or shift in the bacterial composition was observed only after the first month into the intervention. When the two are compared, Clindamycin impacted the gut microbiota greatly more than ciprofloxacin. However, while ciprofloxacin is not associated with the colonization of C. dificile (Dethlefsen et al. 2008), Clindamycin is well documented with causing Clostridium difficile infection (CDI) (Rashid et al. 2015). When administered orally, gram-negative anaerobic and anaerobic bacteria are not affected by Clindamycin. However, this antibiotic had impacts on gram-negative anaerobes and minor impact on Gram-positive aerobic bacteria (Rashid et al. 2015).

\section{Amoxicillin}

Amoxicillin, when combined with clavulanic acid, exerts devastating effects on the gut microbiome. A total wipe of aerobic gram-positive cocci was observed and an associated increase resistant of enterobacteria when individuals are administered with amoxicillin. Fecal samples of a patient suffering from antibiotic-associated diarrhea were analyzed by $16 \mathrm{~S}$ rRNA gene clone libraries (Young and Schmidt 2004). Before the initiation of amoxicillinclavulanate, the gut microbiota comprised mainly of Bacteriodes, Bifidobacterium and Clostridium clusters IV and XIVa (butyrate-producing bacteria). Four days into antibiotic treatment, no sequences corresponding to Bifidobacterium and Clostridium cluster XIVa was detected. However, a marked increase in Enterobacteriaceae was observed. Bacteriodes remained consistent throughout the treatment. Prior to antibiotic initiation, Bacteriodes fragilis were predominant, whereas by day 4, Bacteriodes distasonis became dominant. After cessation of antibiotics, a reversal of the changes was observed, except for Bifidobacterium, which did not return. (De La Cochetiere et al. 2005) also observed major changes in dominant bacterial species using temperature gradient gel electrophoresis (TGGE), during and after a 5-day treatment with amoxicillin in six healthy volunteers.

\section{Clarithromycin}

Clarithromycin, metronidazole, and omeprazole all perturb gut microbiota when used in the treatment of Helicobacter pylori infections. The effects were observed for both short and long term. At the end of the treatment, Firmicutes and Proteobacteria dominated the gut environment, however there was a significant reduction in Actinobacteria. Jakobsson et al. pyrosequencing data also showed that, these antibiotics also had negative impacts on Bifidobacterium. In addition to the reduction of Bifdobacterium, another study reported a drastic reduction 
in Clostridium and Bacteriodes spp. However, none of the patients was colonized with $C$. difficile. An increase in enterococci was also observed (Adamsson et al. 1999).

\section{Cefprozil (cephalosporin 2nd generation)}

In a specific, reproducible and predictable manner, cefprozil-exposed individuals were seen with an increase Lacnoclostridium bolteae. An elevated rate of the occurrence of opportunities pathogens after receiving antibiotic treatment has been observed with lower microbial diversity and profoundly in Bacteriodes enterotype. In addition to the alteration in the gut microbiome, a point mutation in beta-lactamase bla CfxA- 6 was enriched by the antibiotic when compared with resistant genes prior to the intervention of Cefprozil (Raymond et al. 2016). A summary of the varying effects of antibiotics and antibiotics usage against alteration caused to gut microbiota is worth exploring (Tables 1, 2).

\section{Imipenem}

One of the outstanding performance for imipenem is that, among many common antibiotics, it was found to treat Escherichia coli despite, extended-spectrum $\beta$-lactamase (ESBL) genotype (Hoang et al. 2017). Imipenem-cilastatin antibiotic use for the treatment of neutropenic fever was found to be associated with graftversus-host disease (GVHD)-related mortality at 5 years. This treatment brought in loss of protective mucus lining of the colon thereby desrupting the intestinal barrier function with Akkermansia muciniphila expansion. However, despite this pathological evidence with imipenem, it does not affect numbers of regulatory $\mathrm{T}$ cells and SCFAs (Shono et al. 2016). Fecal samples from intensive care patients showed a novel strain with $99 \%$ nucleotide similarities to Sellimonas intestinalis BR72T resistant to antibiotics imipenem (Versluis et al. 2019).

\section{Colistin}

A combination of colistin and amoxicillin was found to induced antibiotic resistome and altered gut microbiota. This shift could not be completely recovered to baseline even after FMT treatment (Li et al. 2021). Phenotypic colistin-resistance associated plasmid-mediated mobile colistin resistance $(\mathrm{mcr})$ genes was found very prominent in chicken-gut bacteria. About $61.7 \%$ of the samples were found to developed resistance to colistin (Islam et al. 2020). Among the last resort antibiotics is colistin. However, of recent, mcr genes in some common bacteria are posing antibiotic resistant to this antibiotic treatment. In addition to Suterella and Parasuterella, all of the other genus Escherichia, Campylobacter and Vibrio carries mcr-like genes. With the knowledge that in Sutterella. wadsworthensis mor-like genes fused to a PAP2-like domain will lay forward some insights into the genetic mobility and strain-specific colisitn resistant (Andrade et al. 2021). A reduced number of Phascolarctobacterium succinatutens, Prevotella copri, Prevotella stercorea and expansion of Acidaminococcus fermentans and Treponema succinifaciens in a study of colistin on gut microbiome composition in pig. In addition, the dominant signaling pathway induced by colisitin intervening group were mitogen-activated protein kinase signaling pathway-yeast, various types of $\mathrm{N}$-glycan biosynthesis, pathogenic Escherichia coli infection, protein processing in endoplasmic reticulum and oxidative phosphorylation (Guo et al. 2021).

\section{Prospects}

The type of antibiotic, the mode of mechanism and the level of resistance determines how it affects the targeted population and the residential microbes. Besides the type-specific effects or alteration of gut microbiota by specific antibiotics, the dosage and duration of antibiotic treatment, route of administration, the pharmacokinetic and pharmacodynamics properties and the spectrum of the antibiotic agent all confer variable alteration to the gut microbiota. The variation in individual gut response on the baseline antibiotics treatment should as well be considered as confounding factors. These are the health status of the person and stress or the type of diet the individual feeds on predominantly. This will lessen the forms of bias in the clinical trials set to establish the effects of antibiotics on the gut. Consequently, depending on the results gathered from short-term intervention alone might not be enough. In essence, long-term natural fluctuations while empirically data are strictly recorded will add more weight on the anticipated Metadata.

The study of resistant genes prior to treatment and after, will answer questions as to the confounding factors leading to such mutations. In fact, in the absences of one bacterial population, gene transfer seems to be prominent among the other groups and in the effect, giving rise to varying resistant genes. More scholarship attention should be centered on effects of antibiotics of the gut microbiota leading to antibacterial resistance. Unlike bacteria, studies have established that gut virome is stable over 12 to 26 months and even individual specific, meaning there is no 'core gut virome'. Bacteriophages are seen to exert effects on FMT treatment of CDI (Zuo et al. 2018).

Antibiotics are meant to target the bad bacterial population. However, their chemical composition will alter the interspecies relationship. Furthermore, there are still very limited to based arguments on. Most of the virus living in the human gut are bacteriophages. When considering the principle of antibiotics, it has similar functions with these 
bacteriophages. However, there is a knowledge gap as to understanding the interaction among the pathogens, the benign bacteria, and the bacteriophages. The study of microbiota is no doubt beyond the characterization of diverse communities; it should encompass the total sum of the dynamic interaction among all the microbes, the host and the external factors. We might say that it is still at the infancy since only bacteria are explored to a larger extent. We still don't know the viral species co-inhabiting human cells. Since the bacteriophages presentable over time, is not exactly the same with the other person, what phage composition is there to limit the bacterial growth? What phyla of bacteria are affected in order to establish a healthy-like gut is a potential research scholarship. In order to have an insight into what the futures of our gut microbiota with respect to the physiological response to disturbance and the changes that these disturbances might bring in, a baseline temporal variation is required (Zaura et al. 2015).

A baseline of gut virome is exactly what we need to ascertain as to what composition signals a healthy gut. This begs for a broad study that must consider the lifestyle of the cohort at study. The geographical differences and ethnicity since the data will serve as the baseline for the preceding researches. Apparently, the alteration inflicted upon by antimicrobial intervention will be evaluated. Furthermore, knowing what a healthy gut is comprised of, with respect to virome will lead ways to the study of gut-related viral diseases. However, from the emerging data, almost $99 \%$ of the gut virus is unknown. To rely on the existing sequence database in establishing the baseline is worth not taken. Assembling the reads into overlapping DNA sequences in a bid to predict protein-coding genes for uniformity is hoped to provide clues as to the type virus.
The interventions that this review will predict in order to reduced the antibiotic induced dysbiosis in the gut are; the use of prophylactic antibiotics should be reduced and devising alternatives to antibiotics during pregnancy. Again, studies should be designed to elucidate on the influence of gut microbiome composition and resistome being affected by antibiotic treatment during pregnancy and lactation. Also the mechanisms in which antibiotics can reach mothers milk and concentrations are enough to affect the breast milk microbiome. It will be prudent enough to know with time, how antibiotic influence microbial diversity and the recovery. Moreover, at strain level, transfer of resistant bacteria in utero should be investigated as to affecting early gut colonization. This should be jointly studied with the risk factors for transmission. Altogether, these could help in establishing healthy gut among mothers and their offsprings.

\section{Conclusion}

In summary, our review showed that both gram-positive and gram-negative bacteria are disrupted with broad-spectrum antibiotics as oppose to narrow spectrum antibiotics. However, what limits interventions to mitigate towards these damages the gut microbiota is our inadequate knowledge in antibiotic activity spectra, the resistant mechanisms of gut microbes against various used antibiotics and the extent of damages specific antibiotics caused. While non antibiotics such as probiotics contribute to microbiome-facilitated antibiotic resistance, the interactions between drugs and microbiome are found to be bidirectional. Antibiotics can disrupt gut microbiota and microbes as well can modulate the drugs thereby modifying the chemical composition and leads to the antimicrobial resistance. Now, our hopes are precision medicine, resistant gene 


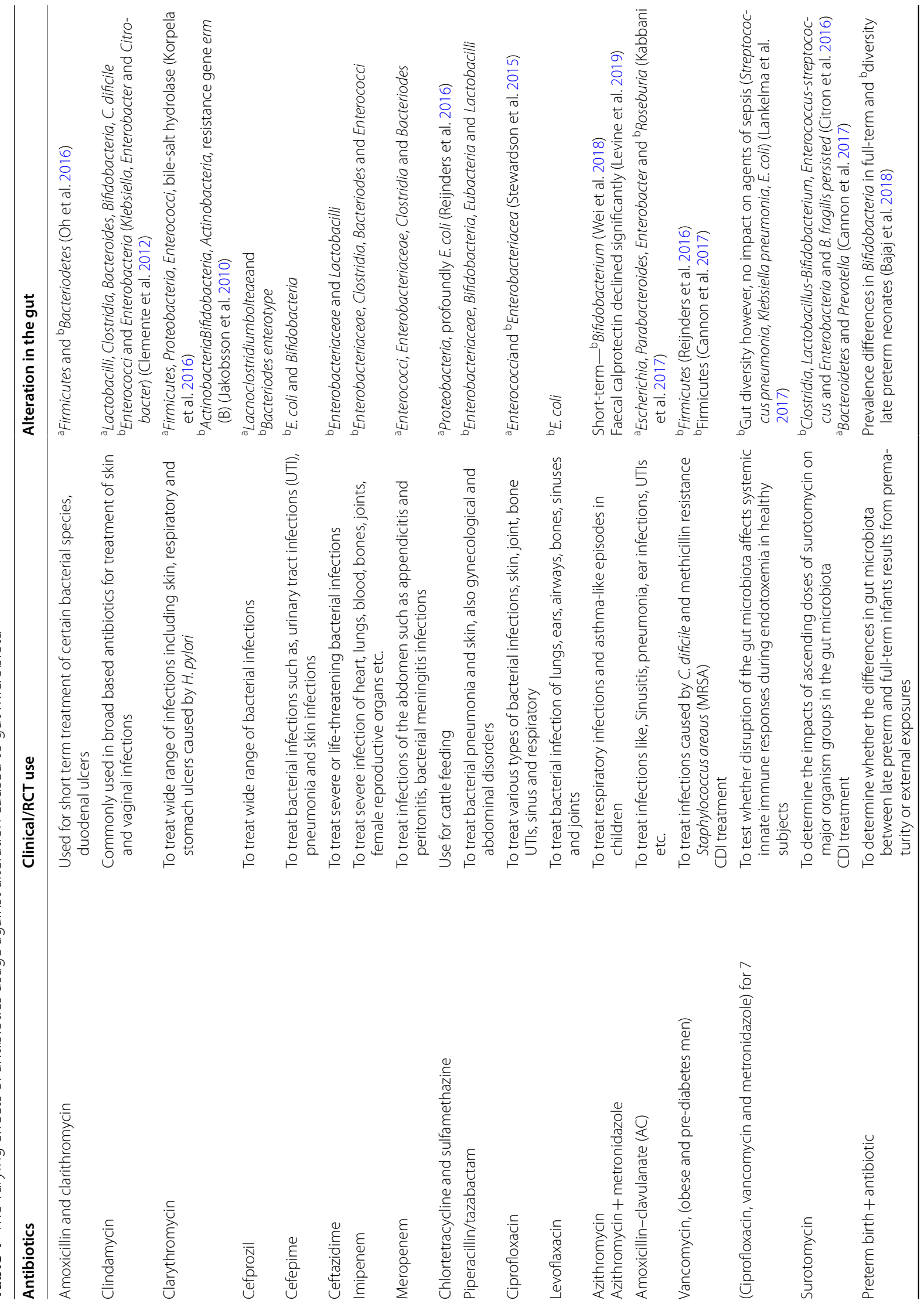




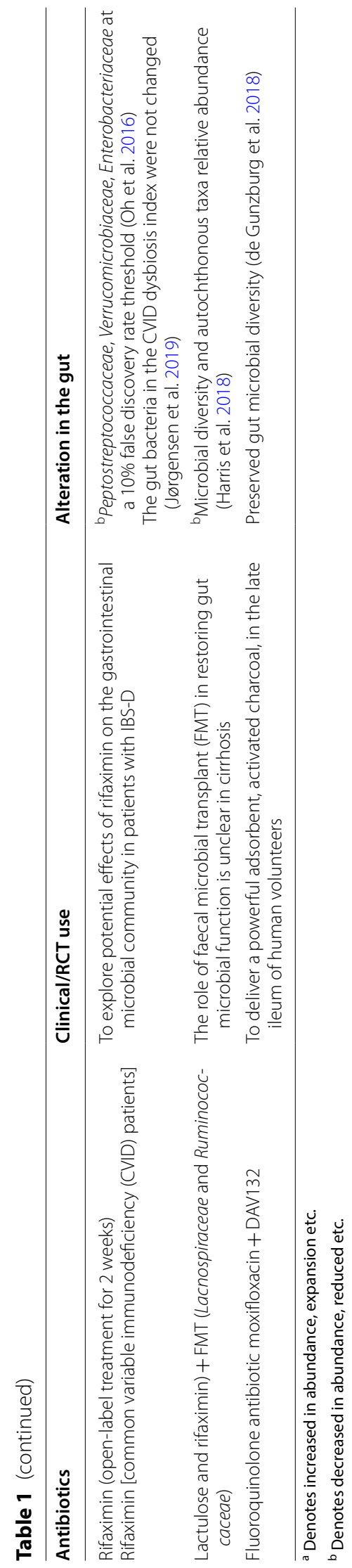


Table 2 The varying effects of probiotics and prebiotics, and other used drugs on gut microbiota

\begin{tabular}{|c|c|c|}
\hline Drug & Medicinal use & Alteration in the gut \\
\hline Proton pump inhibitors (PPIs) & $\begin{array}{l}\text { To treat dyspepsia } \\
\text { To eradicate H. pylori in the treatment of peptic } \\
\text { ulcer, for Gastro reflux and Barrett's esophagus }\end{array}$ & $\begin{array}{l}\text { a Rothia, Enterococcus, Streptococcus, Staphylococ- } \\
\text { cus and the potentially pathogenic species } \\
\text { Escherichia coli (Jackson et al. 2016) } \\
\text { bShannon9s diversity }\end{array}$ \\
\hline Antidepressants & To balance neurotransmitters & $\begin{array}{l}\text { a Eubacterium ramulus, Clostridium } \\
{ }^{\mathrm{b}} \text { E. coli }\end{array}$ \\
\hline Laxatives & $\begin{array}{l}\text { Treatment and prevention of constipation that } \\
\text { affects up to } 17 \% \text { of European adults yearly }\end{array}$ & $\begin{array}{l}\text { aEnterobacteria and Streptococcus. Also, laxatives } \\
\text { decrease Lactobacilli causing intestinal perme- } \\
\text { ability }\end{array}$ \\
\hline Oral steroids & Anti inflammatory therapy & $\begin{array}{l}\text { aMethanogenic bacteria associated with obesity } \\
\text { and also an escalating BMI }\end{array}$ \\
\hline $\begin{array}{l}\text { Drinking water of Electrochemically reduced } \\
\text { alkaline }(\mathrm{pH} \approx 9)\end{array}$ & $\begin{array}{l}\text { To determine electrochemically reduced alkaline } \\
(\mathrm{pH} \approx 9) \text { versus neutral }(\mathrm{pH} \approx 7) \text { drinking water } \\
(2 \mathrm{~L} / \text { day) on human gut microbiota and host } \\
\text { glucose metabolism }\end{array}$ & 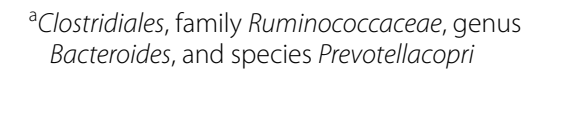 \\
\hline Metformin & Metformin is used to treat Type 2 diabetes & E. coli is predominantly seen \\
\hline Probiotics & Medicinal use & Alteration in the gut \\
\hline $\begin{array}{l}\text { Probiotics Lactobacillus rhamnosus GG } \\
\qquad\left(5 \times 10^{9} \mathrm{cfu}\right)\end{array}$ & $\begin{array}{l}\text { To ameliorate the effects of antibiotic use or } \\
\text { caesarean birth on infant microbiota }\end{array}$ & $\begin{array}{l}\text { Only breastfed infants showed the } \\
\text { a Bifidobacteria } \\
\text { bProteobacteria and Clostridia (Korpela et al. 2018) }\end{array}$ \\
\hline Auto-FMT during allo-HSCT treatment & To re-establish depleted gut commensal & $\begin{array}{l}\text { aMicrobial diversity and reestablished the intesti- } \\
\text { nal microbiota composition (Taur et al. 2018) }\end{array}$ \\
\hline $\begin{array}{l}6 \mathrm{~g} / \text { day prebiotics inulin-type fructans or } \\
\text { maltodextrin }\end{array}$ & $\begin{array}{l}\text { To reduce febrile episodes requiring medi- } \\
\text { cal attention and to lower the incidence of } \\
\text { sinusitis }\end{array}$ & $\begin{array}{l}\text { a Bifidobacterium (with antibiotics) } \\
{ }^{\mathrm{b}} \text { Bifidobacterium (non-antibiotic) (Soldi et al. 2019) }\end{array}$ \\
\hline Probiotics intervention of Bifidobacterium spp. & $\begin{array}{l}\text { To determine the effects of a Bifidobacteria- } \\
\text { containing formula on the healthy human } \\
\text { intestinal microbiome during the first year of } \\
\text { life }\end{array}$ & ${ }^{\mathrm{b}}$ Bacteroides and Blautia spp. (Bazanella et al. 2017) \\
\hline Synbiotics therapy & $\begin{array}{l}\text { To evaluate whether Synbiotic (pre- and probi- } \\
\text { otics) therapy alters the gut microbiota }\end{array}$ & $\begin{array}{l}{ }^{a} \text { Bifidobacterium } \\
{ }^{b} \text { Ruminococcaceae (Zuo et al. 2018) }\end{array}$ \\
\hline $\begin{array}{l}\text { Concomitant therapy antibiotic + probiotics } \\
\text { regimen }\end{array}$ & $\begin{array}{l}\text { To investigate the effects of a commonly used } \\
\text { anti-Helicobacter pylori concomitant therapy } \\
\text { on the composition of the gut and throat } \\
\text { microbiota }\end{array}$ & $\begin{array}{l}\text { Several alteration based on fecal culture however } \\
\text { reverted by day } 71 \text { with the exception yeast and } \\
\text { Bacteroides spp. (Wang et al. 2017) }\end{array}$ \\
\hline $\begin{array}{l}\text { Broad-spectrum (oral vancomycin, ciprofloxacin, } \\
\text { metronidazole) }\end{array}$ & $\begin{array}{l}\text { To test if microbiome modulation can improve } \\
\text { oral rotavirus vaccine (RV) immunogenicity }\end{array}$ & $\begin{array}{l}{ }^{\mathrm{b}} \text { Gut bacterial beta diversity and alters the } \\
\text { immune response to RVV (Harris et al. 2018) }\end{array}$ \\
\hline
\end{tabular}

a Denotes increasing or expansion

${ }^{\mathrm{b}}$ Denotes decreasing or reduction in number

therapy and system biology approaches to leverage the host microbe interaction with an effective and safe treatment strategies.

\section{Annex}

\section{See Tables 1, 2.}

\section{Abbreviations}

AC: Amoxicillin-clavulanate; BMI: Body mass index; CDI: Clostridium difficile infection; CVID: Common variable immunodeficiency; FMT: Faecal microbial transplant; GVHD: Graft-versus-host disease; HGT: Horizontal gene transfer; mrc: Colistin resistance; MRSA: Methicillin resistance Staphylococcus areaus; RCT: Randomized controlled trial; rep-PCR: Repetitive sequence-based PCR;
RCG: Reference gene catalogue; SCFAs: Short chain fatty acids; TGGE: Temperature gradient gel electrophoresis; tet 4: Tigecycline-inactivating enzyme Tet (X4); UTI: Urinary tract infections.

\section{Acknowledgements}

Not applicable.

\section{Authors' contributions}

LY and OB wrote the paper, POJ, YT, AJT and GÖ proofread the paper. All authors read and approved the final manuscript.

\section{Funding}

The publication fee will be reimbursed by Central South University.

\section{Availability of data and materials}

Not applicable. 


\section{Declarations}

Ethics approval and consent to participate

Not applicable.

\section{Consent for publication}

Not applicable.

\section{Competing interests}

The authors declare no competing interests.

\section{Author details}

${ }^{1}$ Department of Medical Microbiology, Central South University, Changsha, Hunan, China. ${ }^{2}$ China-Africa Research Center of Infectious Diseases, School of Basic Medical Sciences, Central South University, Changsha 410078, Hunan, China. ${ }^{3}$ School of Medicine and Allied Health Sciences, University of The Gambia, Serrekunda, Gambia. ${ }^{4}$ Department of Microbiology, University of Nottingham, Nottingham, UK. ${ }^{5}$ Section of Basic and Industrial Microbiology, Department of Biology, Faculty of Science, Ege University, Izmir, Turkey. ${ }^{6}$ Department of Microbiology, Xiangya School of Medicine, Central South University, Changsha 410078, Hunan, China.

Received: 27 July 2021 Accepted: 3 August 2021

Published online: 16 August 2021

\section{References}

Adamsson I, Nord CE, Lundquist P, Sjöstedt S, Edlund C (1999) Comparative effects of omeprazole, amoxycillin plus metronidazole versus omeprazole, clarithromycin plus metronidazole on the oral, gastric and intestinal microflora in Helicobacter pylori-infected patients. J Antimicrob Chemother 44(5):629-640

Adebowale OO, Adeyemo FA, Bankole N, Olasoju M, Adesokan HK, Fasanmi O, Adeyemo O, Awoyomi O, Kehinde O, Fasina FO (2020) Farmers' perceptions and drivers of antimicrobial use and abuse in commercial pig production, Ogun State, Nigeria. Int J Environ Res Public Health 17(10):3579

Alhasan MM, Cait AM, Heimesaat MM, Blaut M, Klopfleisch R, Wedel A, Conlon TM, Yildirim AÖ, Sodemann EB, Mohn WW, Bereswill S, Conrad ML (2020) Antibiotic use during pregnancy increases offspring asthma severity in a dose-dependent manner. Allergy 75(8):1979-1990

Andrade BGN, Goris T, Afli H, Coutinho FH, Dávila AMR, Cuadrat RRC (2021) Putative mobilized colistin resistance genes in the human gut microbiome. BMC Microbiol 21(1):220

Bäckhed F, Fraser CM, Ringel Y, Sanders ME, Sartor RB, Sherman PM, Versalovic J, Young V, Finlay BB (2012) Defining a healthy human gut microbiome: current concepts, future directions, and clinical applications. Cell Host Microbe 12(5):611-622

Bajaj JS, Kakiyama G, Savidge T, Takei H, Kassam ZA, Fagan A, Gavis EA, Pandak WM, Nittono H, Hylemon PB, Boonma P, Haag A, Heuman DM, Fuchs M, John B, Sikaroodi M, Gillevet PM (2018) Antibiotic-associated disruption of microbiota composition and function in cirrhosis is restored by fecal transplant. Hepatology 68(4):1549-1558

Bajinka O, Tan Y, Abdelhalim KA, Özdemir G, Qiu X (2020a) Extrinsic factors influencing gut microbes, the immediate consequences and restoring eubiosis. AMB Express 10(1):130

Bajinka O, Darboe A, Tan Y, Abdelhalim KA, Cham LB (2020b) Gut microbiota and the human gut physiological changes. Ann Microbiol 70:65

Bajinka O, Simbilyabo L, Tan Y, Jabang J, Saleem SA (2021) Lung-brain axis. Crit Rev Microbiol. https://doi.org/10.1080/1040841X.2021.1960483

Bazanella M, Maier TV, Clavel T, Lagkouvardos I, Lucio M, Maldonado-Gòmez MX, Autran C, Walter J, Bode L, Schmitt-Kopplin P, Haller D (2017) Randomized controlled trial on the impact of early-life intervention with bifidobacteria on the healthy infant fecal microbiota and metabolome. Am J Clin Nutr 106(5):1274-1286

Caballero-Flores G, Pickard JM, Fukuda S, Inohara N, Núñez G (2020) An enteric pathogen subverts colonization resistance by evading competition for amino acids in the gut. Cell Host Microbe 28(4):526-533

Cannon K, Byrne B, Happe J, Wu K, Ward L, Chesnel L, Louie T (2017) Enteric microbiome profiles during a randomized Phase 2 clinical trial of surotomycin versus vancomycin for the treatment of Clostridium difficile infection. J Antimicrob Chemother 72(12):3453-3461

Cardetti M, Rodríguez S, Sola A (2020) Uso (y abuso) de antibióticos en la medicina perinatal [Use (and abuse) of antibiotics in perinatal medicine). An Pediatr (Engl Ed) 93(3):207.e1-207.e7

Citron DM, Tyrrell KL, Dale SE, Chesnel L, Goldstein EJ (2016) Impact of surotomycin on the gut microbiota of healthy volunteers in a phase 1 clinical trial. Antimicrob Agents Chemother 60(4):2069-2074

Clemente JC, Ursell LK, Parfrey LW, Knight R (2012) The impact of the gut microbiota on human health: an integrative view. Cell 148(6):1258-1270

Cox LM, Blaser MJ (2015) Antibiotics in early life and obesity. Nat Rev Endocrinol 11(3):182-190

Cui J, Xiao M, Liu M, Wang Z, Liu F, Guo L, Meng H, Zhang H, Yang J, Deng D, Huang S, Ma Y, Liu C (2017) Coupling metagenomics with cultivation to select host-specific probiotic micro-organisms for subtropical aquaculture. J Appl Microbiol 123(5):1274-1285

Daniali M, Nikfar S, Abdollahi M (2020) Antibiotic resistance propagation through probiotics. Expert Opin Drug Metab Toxicol 16(12):1207-1215

Davies J, Davies D (2010) Origins and evolution of antibiotic resistance. Microbiol Mol Biol Rev 74(3):417-433

de Gunzburg J, Ghozlane A, Ducher A, Le Chatelier E, Duval X, Ruppé E, Armand-Lefevre L, Sablier-Gallis F, Burdet C, Alavoine L, Chachaty E, Augustin V, Varastet M, Levenez F, Kennedy S, Pons N, Mentré F, Andremont A (2018) Protection of the human gut microbiome from antibiotics. J Infect Dis 217(4):628-636

De La Cochetière MF, Durand T, Lepage P, Bourreille A, Galmiche JP, Doré J (2005) Resilience of the dominant human fecal microbiota upon shortcourse antibiotic challenge. J Clin Microbiol 43(11):5588-5592

Dethlefsen L, Relman DA (2011) Incomplete recovery and individualized responses of the human distal gut microbiota to repeated antibiotic perturbation. Proc Natl Acad Sci USA 108(Suppl 1):4554-4561

Dethlefsen L, Huse S, Sogin ML, Relman DA (2008) The pervasive effects of an antibiotic on the human gut microbiota, as revealed by deep 165 rRNA sequencing. PLoS Biol 6(11):e280

Devillard E, McIntosh FM, Paillard D, Thomas NA, Shingfield KJ, Wallace RJ (2009) Differences between human subjects in the composition of the faecal bacterial community and faecal metabolism of linoleic acid. Microbiology (Reading) 155(Pt 2):513-520

Ding Y, Saw WY, Tan LWL, Moong DKN, Nagarajan N, Teo YY, Seedorf H (2020) Emergence of tigecycline- and eravacycline-resistant Tet(X4)-producing Enterobacteriaceae in the gut microbiota of healthy Singaporeans. J Antimicrob Chemother 75(12):3480-3484

Ferreyra JA, Wu KJ, Hryckowian AJ, Bouley DM, Weimer BC, Sonnenburg JL (2014) Gut microbiota-produced succinate promotes C. difficile infection after antibiotic treatment or motility disturbance. Cell Host Microbe 16(6):770-777

Ghoshal UC, Srivastava D, Misra A, Ghoshal U (2016) A proof-of-concept study showing antibiotics to be more effective in irritable bowel syndrome with than without small-intestinal bacterial overgrowth: a randomized, double-blind, placebo-controlled trial. Eur J Gastroenterol Hepatol 28(3):281-289

Guo L, Zhang D, Fu S, Zhang J, Zhang X, He J, Peng C, Zhang Y, Qiu Y, Ye C, Liu $Y, W u Z$, Hu CA (2021) Metagenomic sequencing analysis of the effects of colistin sulfate on the pig gut microbiome. Front Vet Sci 8:663820

Hansen TH, Thomassen MT, Madsen ML, Kern T, Bak EG, Kashani A, Allin KH, Hansen T, Pedersen O (2018) The effect of drinking water $\mathrm{pH}$ on the human gut microbiota and glucose regulation: results of a randomized controlled cross-over intervention. Sci Rep 8(1):16626

Harris VC, Haak BW, Handley SA, Jiang B, Velasquez DE, Hykes BL Jr, Droit L, Berbers GAM, Kemper EM, van Leeuwen EMM, Boele van Hensbroek M, Wiersinga WJ (2018) Effect of antibiotic-mediated microbiome modulation on rotavirus vaccine immunogenicity: a human randomized-control proof-of-concept trial. Cell Host Microbe 24(2):197-207

Helaly AMN, El-Attar YA, Khalil M, Ahmed Ghorab DSE, El-Mansoury AM (2019) Antibiotic abuse induced histopathological and neurobehavioral disorders in mice. Curr Drug Saf 14(3):199-208

Hoang PH, Awasthi SP, Do Nguyen P, Nguyen NL, Nguyen DT, Le NH, Van Dang C, Hinenoya A, Yamasaki S (2017) Antimicrobial resistance profiles and molecular characterization of Escherichia coli strains isolated from healthy adults in Ho Chi Minh City, Vietnam. J Vet Med Sci 79(3):479-485 
Holmes M, Flaminio Z, Vardhan M, Xu F, Li X, Devinsky O, Saxena D (2020) Cross talk between drug-resistant epilepsy and the gut microbiome. Epilepsia 61(12):2619-2628

Huang YL, Chassard C, Hausmann M, von Itzstein M, Hennet T (2015) Sialic acid catabolism drives intestinal inflammation and microbial dysbiosis in mice. Nat Commun 6:8141

Imhann F, Bonder MJ, Vich Vila A, Fu J, Mujagic Z, Vork L, Tigchelaar EF, Jankipersadsing SA, Cenit MC, Harmsen HJ, Dijkstra G, Franke L, Xavier RJ, Jonkers D, Wijmenga C, Weersma RK, Zhernakova A (2016) Proton pump inhibitors affect the gut microbiome. Gut 65(5):740-748

Islam S, Urmi UL, Rana M, Sultana F, Jahan N, Hossain B, Iqbal S, Hossain MM, Mosaddek ASM, Nahar S (2020) High abundance of the colistin resistance gene mcr-1 in chicken gut-bacteria in Bangladesh. Sci Rep 10(1):17292

Jackson MA, Goodrich JK, Maxan ME, Freedberg DE, Abrams JA, Poole AC, Sutter JL, Welter D, Ley RE, Bell JT, Spector TD, Steves CJ (2016) Proton pump inhibitors alter the composition of the gut microbiota. Gut 65(5):749-756

Jakobsson HE, Jernberg C, Andersson AF, Sjölund-Karlsson M, Jansson JK, Engstrand L (2010) Short-term antibiotic treatment has differing long-term impacts on the human throat and gut microbiome. PLoS ONE 5(3):e9836

Jernberg C, Löfmark S, Edlund C, Jansson JK (2010) Long-term impacts of antibiotic exposure on the human intestinal microbiota. Microbiology (Reading) 156(Pt 11):3216-3223

Jiao J, Wu J, Wang M, Zhou C, Zhong R, Tan Z (2018) Rhubarb supplementation promotes intestinal mucosal innate immune homeostasis through modulating intestinal epithelial microbiota in goat kids. J Agric Food Chem 66(4):1047-1057

Jørgensen SF, Macpherson ME, Bjørnetrø T, Holm K, Kummen M, Rashidi A, Michelsen AE, Lekva T, Halvorsen B, Trøseid M, Mollnes TE, Berge RK, Yndestad A, Ueland T, Karlsen TH, Aukrust P, Hov JR, Fevang B (2019) Rifaximin alters gut microbiota profile, but does not affect systemic inflammation - a randomized controlled trial in common variable immunodeficiency. Sci Rep 9(1):167

Kabbani TA, Pallav K, Dowd SE, Villafuerte-Galvez J, Vanga RR, Castillo NE, Hansen J, Dennis M, Leffler DA, Kelly CP (2017) Prospective randomized controlled study on the effects of Saccharomyces boulardii CNCM I-745 and amoxicillin-clavulanate or the combination on the gut microbiota of healthy volunteers. Gut Microbes 8(1):17-32

Korpela K, Salonen A, Virta LJ, Kekkonen RA, Forslund K, Bork P, de Vos WM (2016) Intestinal microbiome is related to lifetime antibiotic use in Finnish pre-school children. Nat Commun 7:10410

Korpela K, Salonen A, Vepsäläinen O, Suomalainen M, Kolmeder C, Varjosalo M, Miettinen S, Kukkonen K, Savilahti E, Kuitunen M, de Vos WM (2018) Probiotic supplementation restores normal microbiota composition and function in antibiotic-treated and in caesarean-born infants. Microbiome 6(1):182

Langdon A, Crook N, Dantas G (2016) The effects of antibiotics on the microbiome throughout development and alternative approaches for therapeutic modulation. Genome Med 8(1):39

Lange K, Buerger M, Stallmach A, Bruns T (2016) Effects of antibiotics on gut microbiota. Dig Dis 34(3):260-268

Lankelma JM, Cranendonk DR, Belzer C, de Vos AF, de Vos WM, van der Poll T, Wiersinga WJ (2017) Antibiotic-induced gut microbiota disruption during human endotoxemia: a randomised controlled study. Gut 66(9):1623-1630

Levine A, Kori M, Kierkus J, Sigall Boneh R, Sladek M, Escher JC, Wine E, Yerushalmi B, Amil Dias J, Shaoul R, Veereman Wauters G, Boaz M, Abitbol G, Bousvaros A, Turner D (2019) Azithromycin and metronidazole versus metronidazole-based therapy for the induction of remission in mild to moderate paediatric Crohn's disease : a randomised controlled trial. Gut 68(2):239-247

Li L, Wang Q, Gao Y, Liu L, Duan Y, Mao D, Luo Y (2021) Colistin and amoxicillin combinatorial exposure alters the human intestinal microbiota and antibiotic resistome in the simulated human intestinal microbiota. Sci Total Environ 750:141415

Liu D, Tan Y, Bajinka O, Wang L, Tang Z (2020b) Th17/IL-17 axis regulated by airway microbes get involved in the development of asthma. Curr Allergy Asthma Rep 20(4):11

Liu J, Chen F, Wang X, Peng H, Zhang H, Wang KJ (2020a) The synergistic effect of mud crab antimicrobial peptides sphistin and $\mathrm{Sph}_{12-38}$ with antibiotics azithromycin and rifampicin enhances bactericidal activity against Pseudomonas aeruginosa. Front Cell Infect Microbiol 10:572849
Looft T, Johnson TA, Allen HK, Bayles DO, Alt DP, Stedtfeld RD, Sul WJ, Stedtfeld TM, Chai B, Cole JR, Hashsham SA, Tiedje JM, Stanton TB (2012) In-feed antibiotic effects on the swine intestinal microbiome. Proc Natl Acad Sci USA 109(5):1691-1696

Munita JM, Arias CA (2016) Mechanisms of antibiotic resistance. Microbiol Spectr. https://doi.org/10.1128/microbiolspec.VMBF-0016-2015

Oh B, Kim BS, Kim JW, Kim JS, Koh SJ, Kim BG, Lee KL, Chun J (2016) The effect of probiotics on gut microbiota during the Helicobacter pylori eradication: randomized controlled trial. Helicobacter 21(3):165-174

Olmos Soto J (2021) Feed intake improvement, gut microbiota modulation and pathogens control by using Bacillus species in shrimp aquaculture. World J Microbiol Biotechnol 37(2):28

Ouwehand A, Isolauri E, Salminen S (2002) The role of the intestinal microflora for the development of the immune system in early childhood. Eur J Nutr 41(Suppl 1):132-137

Pang Z, Raudonis R, Glick BR, Lin TJ, Cheng Z (2019) Antibiotic resistance in Pseudomonas aeruginosa: mechanisms and alternative therapeutic strategies. Biotechnol Adv 37(1):177-192

Patangia DV, Ryan CA, Dempsey E, Stanton C, Ross RP (2021) Vertical transfer of antibiotics and antibiotic resistant strains across the mother/baby axis. Trends Microbiol. https://doi.org/10.1016/j.tim.2021.05.006

Qiu X, Ye Q, Sun M, Wang L, Tan Y, Wu G (2020) Saturated hydrogen improves lipid metabolism disorders and dysbacteriosis induced by a high-fat diet. Exp Biol Med (maywood) 245(6):512-521

Qiu X, Bajinka O, Wang L, Wu G, Tan Y (2021) Effects of high-fat diet on the epithelial mesenchymal transition of respiratory tract through the glyoxylic acid cycle of pulmonary microbes and the intervention of saturated hydrogen. Am J TransI Res 13(6):6016-6030

Rashid MU, Zaura E, Buijs MJ, Keijser BJ, Crielaard W, Nord CE, Weintraub A (2015) Determining the long-term effect of antibiotic administration on the human normal intestinal microbiota using culture and pyrosequencing methods. Clin Infect Dis 60(Suppl 2):S77-84

Raymond F, Ouameur AA, Déraspe M, labal N, Gingras H, Dridi B, Leprohon P, Plante PL, Giroux R, Bérubé Ė, Frenette J, Boudreau DK, Simard JL, Chabot I, Domingo MC, Trottier S, Boissinot M, Huletsky A, Roy PH, Ouellette M, Bergeron MG, Corbeil J (2016) The initial state of the human gut microbiome determines its reshaping by antibiotics. ISME J 10(3):707-720

Reijnders D, Goossens GH, Hermes GD, Neis EP, van der Beek CM, Most J, Holst J, Lenaerts K, Kootte RS, Nieuwdorp M, Groen AK, Olde Damink SW, Boekschoten MV, Smidt H, Zoetendal EG, Dejong CH, Blaak EE (2016) Effects of gut microbiota manipulation by antibiotics on host metabolism in obese humans: a randomized double-blind placebocontrolled trial. Cell Metab 24(1):63-74

Shono Y, Docampo MD, Peled JU, Perobelli SM, Velardi E, Tsai JJ, Slingerland AE, Smith OM, Young LF, Gupta J, Lieberman SR, Jay HV, Ahr KF, Porosnicu Rodriguez KA, Xu K, Calarfiore M, Poeck H, Caballero S, Devlin SM, Rapaport F, Dudakov JA, Hanash AM, Gyurkocza B, Murphy GF, Gomes C, Liu C, Moss EL, Falconer SB, Bhatt AS, Taur Y, Pamer EG, van den Brink MRM, Jenq RR (2016) Increased GVHD-related mortality with broad-spectrum antibiotic use after allogeneic hematopoietic stem cell transplantation in human patients and mice. Sci Transl Med 8(339):339ra71

Soldi S, Vasileiadis S, Lohner S, Uggeri F, Puglisi E, Molinari P, Donner E, Sieland C, Decsi T, Sailer M, Theis S (2019) Prebiotic supplementation over a cold season and during antibiotic treatment specifically modulates the gut microbiota composition of 3-6 year-old children. Benef Microbes 10(3):253-263

Stewardson AJ, Gaïa N, François P, Malhotra-Kumar S, Delémont C, Martinez de Tejada B, Schrenzel J, Harbarth S, Lazarevic V (2015) SATURN WP1 and WP3 Study Groups. Collateral damage from oral ciprofloxacin versus nitrofurantoin in outpatients with urinary tract infections: a culture-free analysis of gut microbiota. Clin Microbiol Infect 21(4):344. e1-344.e11

Taur Y, Coyte K, Schluter J, Robilotti E, Figueroa C, Gjonbalaj M, Littmann ER, Ling L, Miller L, Gyaltshen Y, Fontana E, Morjaria S, Gyurkocza B, Perales MA, Castro-Malaspina H, Tamari R, Ponce D, Koehne G, Barker J, Jakubowski A, Papadopoulos E, Dahi P, Sauter C, Shaffer B, Young JW, Peled J, Meagher RC, Jenq RR, van den Brink MRM, Giralt SA, Pamer EG, Xavier JB (2018) Reconstitution of the gut microbiota of 
antibiotic-treated patients by autologous fecal microbiota transplant. Sci Transl Med 10(460):eaap9489

Theriot CM, Koenigsknecht MJ, Carlson PE Jr, Hatton GE, Nelson AM, Li B, Huffnagle GB, Li JZ, Young VB (2014) Antibiotic-induced shifts in the mouse gut microbiome and metabolome increase susceptibility to Clostridium difficile infection. Nat Commun 5:3114

Tochitani S (2021) Vertical transmission of gut microbiota: Points of action of environmental factors influencing brain development. Neurosci Res 168:83-94

Uzan-Yulzari A, Turta O, Belogolovski A, Ziv O, Kunz C, Perschbacher S, Neuman H, Pasolli E, Oz A, Ben-Amram H, Kumar H, Ollila H, Kaljonen A, Isolauri E, Salminen S, Lagström H, Segata N, Sharon I, Louzoun Y, Ensenauer R, Rautava S, Koren O (2021) Neonatal antibiotic exposure impairs child growth during the first six years of life by perturbing intestinal microbial colonization. Nat Commun 12(1):443

Versluis D, de J. Bello González T, Zoetendal EG, Passel MWJV, Smidt H (2019) High throughput cultivation-based screening on porous aluminum oxide chips allows targeted isolation of antibiotic resistant human gut bacteria. PLOS ONE 14(1):e0210970

Vincent C, Manges AR (2015) Antimicrobial use, human gut microbiota and Clostridium difficile colonization and infection. Antibiotics (Basel) 4(3):230-253

Vogt SL, Finlay BB (2017) Gut microbiota-mediated protection against diarrheal infections. J Travel Med 24(suppl_1):S39-S43

Vuong HE, Pronovost GN, Williams DW, Coley EJL, Siegler EL, Qiu A, Kazantsev M, Wilson CJ, Rendon T, Hsiao EY (2020) The maternal microbiome modulates fetal neurodevelopment in mice. Nature 586(7828):281-286

Wang ZJ, Chen XF, Zhang ZX, Li YC, Deng J, Tu J, Song ZQ, Zou QH (2017) Effects of anti-Helicobacter pylori concomitant therapy and probiotic supplementation on the throat and gut microbiota in humans. Microb Pathog 109:156-161

Wang C, Li P, Yan Q, Chen L, Li T, Zhang W, Li H, Chen C, Han X, Zhang S, Xu M, Li B, Zhang X, Ni H, Ma Y, Dong B, Li S, Liu S (2019) Characterization of the pig gut microbiome and antibiotic resistome in industrialized feedlots in China. mSystems 4(6):e00206-19

Wei S, Mortensen MS, Stokholm J, Brejnrod AD, Thorsen J, Rasmussen MA Trivedi U, Bisgaard H, Sørensen SJ (2018) Short- and long-term impacts of azithromycin treatment on the gut microbiota in children: a doubleblind, randomized, placebo-controlled trial. EBioMedicine 38:265-272

Yoshioka H, Iseki K, Fujita K (1983) Development and differences of intestinal flora in the neonatal period in breast-fed and bottle-fed infants. Pediatrics 72(3):317-321

Young VB, Schmidt TM (2004) Antibiotic-associated diarrhea accompanied by large-scale alterations in the composition of the fecal microbiota. J Clin Microbiol 42(3):1203-1206

Zaura E, Brandt BW, Teixeira de Mattos MJ, Buijs MJ, Caspers MP, Rashid MU, Weintraub A, Nord CE, Savell A, Hu Y, Coates AR, Hubank M, Spratt DA, Wilson M, Keijser BJ, Crielaard W (2015) Same exposure but two radically different responses to antibiotics: resilience of the salivary microbiome versus long-term microbial shifts in feces. Mbio 6(6):e01693-15

Zhang X, Borbet TC, Fallegger A, Wipperman MF, Blaser MJ, Müller A (2021) An antibiotic-impacted microbiota compromises the development of colonic regulatory $T$ cells and predisposes to dysregulated immune responses. Mbio 12(1):e03335-20

Zivkovic AM, German JB, Lebrilla CB, Mills DA (2011) Human milk glycobiome and its impact on the infant gastrointestinal microbiota. Proc Natl Acad Sci USA 108(Suppl 1):4653-4658

Zuo T, Wong SH, Lam K, Lui R, Cheung K, Tang W, Ching JYL, Chan PKS, Chan MCW, Wu JCY, Chan FKL, Yu J, Sung JJY, Ng SC (2018) Bacteriophage transfer during faecal microbiota transplantation in Clostridium difficile infection is associated with treatment outcome. Gut 67(4):634-643

\section{Publisher's Note}

Springer Nature remains neutral with regard to jurisdictional claims in published maps and institutional affiliations.

\section{Submit your manuscript to a SpringerOpen ${ }^{\circ}$ journal and benefit from:}

- Convenient online submission

- Rigorous peer review

- Open access: articles freely available online

- High visibility within the field

- Retaining the copyright to your article

Submit your next manuscript at $\boldsymbol{\nabla}$ springeropen.com 